\title{
Automation Applications in Integrated Animal Production System ${ }^{\#}$
}

\author{
Emre Aydemir ${ }^{1, a, *}$, İnci Bilge ${ }^{2, b}$ \\ ${ }^{I}$ Department of Animal Science, Faculty of Agriculture, Akdeniz University, 07070 Antalya, Turkey \\ ${ }^{2}$ Department of Electricity and Energy, Vocational School of Technical Sciences, Mehmet Akif Ersoy University, 15100 Burdur, Turkey
} *Corresponding author

\begin{tabular}{|c|c|}
\hline A R T I C LE INFO & B S T R A C T \\
\hline $\begin{array}{l}\text { \#This study was presented as an oral } \\
\text { presentation at the } 1^{\text {st }} \text { International } \\
\text { Congress of the Turkish Journal of } \\
\text { Agriculture - Food Science and } \\
\text { Technology (Antalya, TURJAF 2019) }\end{array}$ & $\begin{array}{l}\text { In livestock enterprises, with the developing technology, the use of automation instead of control } \\
\text { with manpower has become widespread. With the use of automation, it provides easy and reliable } \\
\text { production, healthy product, decrease of labor force, prevention of economic losses, periodic and } \\
\text { systematic operation and keeping data record regularly. In this way, it is possible to evaluate all } \\
\text { records of animal production in digital environment. Control element (PC, PLC, PIC, } \\
\text { Microprocessor, Electronic Cards), Activation Element (Motors, Cylinders, motion elements, etc.), } \\
\text { Process (Production, temperature, control, chemical, events, etc.), Adjustment in automation used in } \\
\text { animal husbandry Element (Acceleration, Angle, Speed, Flow, Encoders, Force, Load, Price, } \\
\text { Pressure, Temperature, Slope, Torsion, Vibration Measurement Elements). Thanks to the intelligent } \\
\text { sensors and controllers of these elements, feed and water of animals are recorded from central } \\
\text { computers in automation control. In the studies, S7-300 PLC was used to carry out the general } \\
\text { operation and collect the data. In addition, SCADA is used for central system supervision and } \\
\text { control, data collection and storage, irrigation and feeding, warning and warning for security. In this } \\
\text { study, it is aimed to give information about the use of automation in industrial animal husbandry } \\
\text { enterprises. }\end{array}$ \\
\hline
\end{tabular}

Integrated production

\section{Introduction}

Worldwide, with the increasing population, the nutrient requirement is increasing. One of the sectors that plays an important role in adequate and balanced nutrition of the growing population is the livestock sector. This sector has been created as the source of many raw materials such as meat, milk, eggs, textile, leather, cosmetics and pharmaceutical industries all over the world. According to FAO data, in 2016, the agricultural sector accounted for $3.2 \%$ of the world's gross product, while the livestock sector accounted for $37 \%$ of the gross domestic product. While this ratio is $55 \%$ in EU countries and $46 \%$ in the USA, it has a place of $24 \%$ in developing countries. It contains $19-24 \%$ protein in meat, $12 \%$ in egg, 3-4\% in milk and $15-25 \%$ in cheese. It consumes an average of 81 grams of protein per person worldwide. 32 grams of this are supplied from proteins of animal origin.

In developed countries, the coverage of animal products is around $20 \%$. This rate increases to $65 \%$ in developed countries. With this increasing ratio, manpower decreases with the developing technology in the field of industrial animal husbandry. In recent years, manpower has been rapidly replaced by fully automated systems. With the use of automation, it provides easy and reliable production, healthy product, decrease of labor force, prevention of economic losses, periodic and systematic operation and keeping data record regularly. In this way, all records of animal production can be evaluated in digital environment. In integrated production, environmental factors such as irrigation, feeding, humidification, ventilation, temperature are controlled instantly by automation applications.

Automation elements used in integrated animal production, control element (PC, PLC, PIC, Microprocessor, Electronic Cards), activation element (motors, cylinders, motion elements, etc.), process (production, temperature, control, chemical, events, etc.), Measuring Element (Acceleration, Angle, Speed, Flow, Encoders, Force, Load, Position, Pressure, Temperature, 
Slope, Torsion, Vibration Measurement Elements) are used as. Utilization of computer technologies has become extremely important in terms of production planning.

\section{Automation Control elements}

Control element (PC, PLC, PIC, Microprocessor, Electronic Cards), activation element (Motors, Cylinders, motion elements, etc.), process (Production, temperature, control, chemical, events, etc.) Element (Acceleration, Angle, Speed, Flow, Encoders, Force, Load, Position, Pressure, Temperature, Slope, Torsion, Vibration Measurement Elements) are available.

\section{SCADA system (Supervisory Control and Data Acquisition)}

Central control and data total system is defined as. SCADA systems have expanded to a wide range of facilities from a single center computer, mobile phone, tablet pc and so on. devices can be monitored with a system. It can be operated from a single device or controlled by multiple computers and portable devices via network connections.

\section{PC (Personal Computer)}

It receives the information entered by the users into the data input unit, processes the information entered with the processing unit, stores the obtained results in itself and outputs the results of the processed data to the user with the output unit when desired.

\section{PIC (Peripheral Interface Controller)}

It is a chip which is designed to control $1 / 0$ elements such as lamp, motor, relay, temperature and light sensor very quickly.

\section{PLC (Programmable Logic Controller)}

It provides great convenience in solving complex automation problems in automation systems. The control elements in the PLC are indicated separately by the address. With the commands given to PLC, electric motor, lamp, solenoid valve, contactor, relay can be controlled.

\section{Microprocessors}

Microprocessors are often referred to as the central processing unit (CPU) because they perform all the operations that computer programs want to do.

\section{Studies}

According to TURKSTAT 2014 records, it is stated that there is not a sufficient transition between 2006 and 2013 from 289 milking, milking facilities, electronic automation systems (pulse device, milk flow meter, milking head receiver) of 289 enterprises. Varol A., (1999) in his study, lighting, irrigation and feeding automation for chicken poultry electro-mechanical part of the Fischer Technic robot set, the software reported that the LOGO programming language is used for the part. Akçay et al. (2008) in their study, integrated meat plant automatic irrigation and feeding part of the PLC and SCADA examined and monitored. In this study, the control and monitoring of irrigation-feeding part with PLC and WinCC SCADA program has been realized successfully and the system provides remote monitoring and control automatically thanks to PLC and SCADA programs. In addition, thanks to the PLC and SCADA system control of the facility, efficiency and security have been increased by using less manpower, and the plant has been able to reduce losses and increase efficiency by minimizing human errors, reporting, data archiving, and increasing productivity. reported that they are applicable. Aydın et al., (2010) In their study, land Borland Delphi 7.0" (Borland Delphi Enterprise Version 7.0) programming language was used to develop a software program for keeping technical and financial data in livestock enterprises. In the study, they stated that the milk yield, reproduction and pedigree records required in animal husbandry enterprises can be monitored very visually and easily with the software program.

\section{Result}

As a result of the studies, it has been stated that the use of automation in livestock production systems provides significant contributions and advantages to the world economy with higher quality and more production at minimum cost as well as productivity increases. With the introduction of automation systems into industrial production, it creates new working areas in the livestock sector for different applications of developing technology.

\section{References}

Akçay H, Hasırc1 MG, 2008, Bir Entegre Tesisin Endüstriyel Scada Kontrolü Ve Simülasyonu, Selçuk Üniversitesi, Elektrik-Elektronik Mühendisliği Bölümü, Lisans Bitirme Projesi.

Aydın İ, Günlü A, 2010, Hayvancılık İşletmelerinde Teknik Ve Finansal Verilerin Tutulmasına Ve Değerlendirilmesine Yönelik Bir Bilgisayar Yazılımı Vet Hekim Der Derg 80(4): 21-30.

FAO. 2016, http://www.fao.org/faostat/ (Erişim Tarihi 20.02.2018)

Varol A. 1999, Tavuk Kümesleri İçin Sulama Otomasyonu, Elektrik Elektronik Makine Bilgisayar Dergisi, Sayı: 88, S: 94-99. 